\title{
Smart technology integration into EFL teaching at the non-linguistic higher school
}

\author{
Olga A. Kalugina - Natalya A. Tarasevich
}

DOI: 10.18355/XL.2018.11.01XL.02

\begin{abstract}
This paper considers the investigation of smart technology integration into EFL teaching and assessment at the non-linguistic higher school. The purpose of the paper is to develop, theoretically substantiate and assess the usage of smart technology in EFL teaching at a non-linguistic higher school. The model for integration of smart technologies into the course of «Business Communication» for the students majoring in Economics in an English language learning environment is presented. Some possible blocking factors, challenges educators can face in the educational arena are revealed. The authors highlight didactic characteristics and functions that can be taken into account for smart technology integration. It is noted that understanding of the concept of smart technology integration into EFL teaching, finding an optimal balance between students' needs and teachers' professional competence can lead to significant language learning outcomes.

Key words: smart technology, integration, EFL teaching and assessment, language
\end{abstract} learning environment, blocking factors, didactic characteristics

\section{Introduction}

Smart technology has revolutionized our everyday life mode and become one of the most essential elements in the process of EFL teaching in the XXI century. The range of technologies available for use in language learning and teaching has become very diverse. Some are really useful for testing and assessment, distance learning, teaching ESP, academic English, reading, listening, speaking or interpreting. The integration of multimedia and the Internet in teaching and learning languages makes the process of education more effective and creates motivating smart learning environment (SLE) that is technology -supported learning environment that can make adaptations and provide appropriate support (e.g., guidance, feedback, hints or tools) in the right place and at the right time based on individual learners' needs, which might be determined via analyzing their learning behaviors, performance and the online and real-world contexts in which they are situated (Hwang, 2014).

Moreover, smart technology changes pedagogical and methodological contexts for both teachers and learners. Smart technology offers teachers and learners new modes of curriculum delivery, new forms of communicative interaction, and greater opportunities for immediate feedback (Orden, 2010). Smart technologies tend to make EFL teaching authentic providing students with up-to-date and relevant materials and activities.

What is meant by smart technology? How can we define it? There is not one standard definition for the term «smart technology». According to Oxford Dictionary technology means «the application of scientific knowledge for practical purposes, especially in industry; smart - (of a device) programmed so as to be capable of some independent action» (https://en.oxforddictionaries.com/definition/smart). Based on Oxford dictionary we define smart technologies as technologies which have educational utility, programmed so as to be capable of independent actions giving students and teachers an access to the world outside a classroom. They include a list of digital equipment for smart classrooms such as a digital camera, a scanner, a digital voice recorder, iPod or Mp3 player, an interactive white board, DVD players, PDA, a smart phone, a Tablet PC, a touch-screen computer, a laptop, a desktop student 
computer station, a digital textbook, any software used to create digital media, or digital media that can be accessed with a computer through the Internet or otherwise.

Understanding of the concept of smart technology integration into EFL teaching can lead to significant language learning outcomes. However, despite the fact that we are living in the «age of technology» not all the members of educational process are aware of the importance and the influence of smart technology integration on the daily teaching, many teachers still feel uncomfortable with the idea of integrating it into classrooms. The reasons might be different including negative attitude towards digitalization of educational process in general, «digital illiteracy», lack of tools. We still do not understand enough about the changes to teaching and learning contexts that occur when teachers integrate smart technologies to create and sustain personalized learning environments. One more challenge educators can face in the educational arena is misusage of technologies. To encourage students to be more productive teachers should equip their students with the tools they need to be both productive and responsible.

The purpose of this article is to discuss approaches, which can help satisfy students' needs and highlight the problems, which students and teachers at nonlinguistic higher schools might face while working with smart technologies teaching and studying the foreign languages. Incorporating technology into each stage: planning, lesson delivery, practice and review, assessment and feedback can bring numerous benefits as well as undeniable drawbacks. The aim of this study is to reveal the reasons of smart technology integration into the EFL classroom, investigate specific benefits for English language learners (ELLs) and also highlight diverse repertoire of strategies that maximize the benefits for our students. Teachers should admit the fact that technological tools and supports alone are not the only solutions to help ELLs - or any learners. These tools must be utilized in concert with other strategies that support language acquisition. ELLs face the unique learning challenge of developing skills and content mastery while simultaneously acquiring a new language - often when their native language is not yet fully mastered. This means that teachers must also simultaneously meet these instructional goals. (Vander, 2016). This is an important peculiarity that should not be overlooked. It makes teacher's work quite complicated.

The subject matter of the study is the process of EFL teaching and assessment at the non-linguistic higher school.

The scope of the study is smart technology integration into EFL teaching.

The purpose of this research is to develop, theoretically substantiate and assess the ways of smart technology integration into EFL teaching at a non-linguistic higher school.

The present study was designed to test the hypothesis that the smart technology integration into EFL teaching at the non-linguistic higher school can be effective provided that the content of smart technologies is revealed and justified; the didactic material necessary for its implementation is selected.

\section{Review of Literature}

The role of technology in shaping the future of higher education is evident. The major findings are as follows:

- Technology has had - and will continue to have- a significant impact on higher education

- Online learning is gaining a firm foothold in universities around the world

- Corporate-academic partnerships will form an increasing part of the university experience

XLinguae, Volume 11 Issue 1XL, January 2018, ISSN 1337-8384, eISSN 2453-711X 
- University respondents view technology as having a largely positive impact on their campuses

- Higher education is responding to globalization (https://www.nmc.org/pdf/Future-of-Higher-Ed-(NMC).pdf).

The use of technology in EFL teaching happens to influence the development of linguistic skills. Several researchers have reported the usefulness of using technology in foreign language classrooms (Merç, 2015), (Liton, 2015), (Orden, 2010), (Sandolo, 2010), (Beauvois, 1998). Shyamlee, Phil (2012) analyzed the necessity of multimedia technology to language teaching. They outlined mostly positive aspects such as cultivation of students' interest in study, promotion of students' communication capacity, broadening students' knowledge to gain an insightful understanding to western culture, improvement of teaching effect and interaction between teacher and student, creating a context for language teaching, providing flexibility to course content.

However more and more researchers are concerned about balancing classroom technology use because of the negative psychological effect caused by technologies such as the use of technology rewires the brain (Durocher, 2016). Financing can also prevent a minimum of equipment being procured, both for teaching, tutoring and the students' own work, whether it is individual or group work

(Johannesen, Eide, 2000). Merç's study (2015) revealed a mismatch between teacher training programs and real-world classrooms in terms of technology integration in EFL instruction.

Andrade (2014) examined the role of technology in supporting English language learners in today's classrooms and came up with the idea that the biggest challenges of technology integration into classroom tasks is the role of the teacher. According to Andrade the constant use of technology in the classroom shifts from a teacher-centered classroom to a more student-centered classroom where the relationship between student-centered teaching and the constructivist model in which students construct rather than receive or assimilate knowledge. It results in more effective language acquisition. New form of educational discourses and paradigms facilitate collaborative and learner-centered autonomous responsible learning platform (Liton, 2015). The paradigm of the educational process in the information society has changed qualitatively, the proportion of the basic components:"teacher-studenttextbook", as well as the status, functions and competencies of the teacher and student (Khromov, Romanova, 2013: 113). Some scientist made attempts to integrate theory and practice incorporating teaching tips, ideas and classroom plans concerning technologies' implementation into teaching practices as well as providing activities for self learning and evaluation (Dudeney, Hockly, 2007; Khuziakhmetov, Gabdrakhmanova, 2016; Khuziakhmetov, Nasibullov, 2016; Masalimova et al., 2017; Kong, Kayumova, Zakirova, 2017; Li, Pyrkova , Ryabova, 2017).

Although there were numerous studies regarding the use of smart technology in EFL teaching, studies concerning integration of technology as a tool of assessment in EFL teaching are rather limited. Birova et al. (2016: 2479) raised the problem of old bad habits in language assessment and declared the need of a system of assessment which could help teachers to progress and monitor language development. Klimova et al. (2017) have sought to understand more about effective foreign language learning design and the implications for distance learning tools. Ogurtsova (2015) suggested development of a special web-based Intelligent Business English learning Platform (IBELP) to manage skills and competence development and to make assessment of a student's progress in more transparent and objective way. The approaches to assessing language through computer technology were presented by Chapelle, Douglas (2006). E-assessment has the following advantages over paperbased assessment: instant feedback to students and to a teacher, flexibility in respect 
to timing and location, high reliability, improved impartiality and quick data processing capabilities.

\section{Materials and Methods}

\subsection{Research methods}

The following methods have been used in our research: assessment of the key pedagogical principles of smart technology integration, survey data analysis, evaluation of educational outcomes, interviews, systematization and categorization of facts and concepts.

\subsection{Research Stages}

The research was conducted in three stages.

The first stage involved: studying previous research; defining the subject matter, scope and purpose of the research; developing a hypothesis; formulating research objectives; defining methods appropriate to the purpose and objectives of the study; identifying research facilities.

In the second stage we conducted the survey data analysis to gain an insight into the assessment of students' language acquisition by means of smart technologies in a non-linguistic higher school. We selected smart technologies and integrated them into the course «Business communication». The model for integration of smart technologies into the course «Business Communication» for the students majoring in Economics in an English language learning environment was theoretically justified.

The third stage included investigation of didactic characteristics and functions of smart technologies and the blocking factors of smart technology integration in an English language learning environment; systematization and analysis of the results obtained; drawing conclusions.

\section{Results and discussion}

The purpose of this research paper was the smart technology integration into EFL teaching.

To carry out the research on smart technology integration, three research questions were formulated:

1. What technologies are used for EFL teaching and assessment students' language acquisition?

2. What blocking factors affect the smart technology integration?

3. What didactic characteristics and functions can be taken into account for smart technology integration?

This study included quantitative as well as qualitative data collection tools. We have presented the findings in accordance with the questions in the survey.

A questionnaire was developed by EFL teachers and distributed among 100 first-year students majoring in Economics, taking classes in English, and studying International Finance at the Financial University under the Government of the Russian Federation.

The questionnaire contained 6 items, five of which were designed to investigate the use of technologies as tools of assessment, the level of satisfaction by these means and another one inquired about the advantages and disadvantages of these methods. We asked students to choose an appropriate option that reflects their view on technology as a tool of language assessment:

XLinguae, Volume 11 Issue 1XL, January 2018, ISSN 1337-8384, eISSN 2453-711X 
Table 1: Questionnaire to identify students' attitude towards technology as a tool of language assessment

\begin{tabular}{|c|c|}
\hline \multicolumn{2}{|c|}{$\begin{array}{l}\text { Please help us serve you better by taking a few moments to fill out this survey } \\
\text { form. }\end{array}$} \\
\hline \multicolumn{2}{|c|}{ 1. Do you like technology as a tool for assessment in your classroom? } \\
\hline Yes & No \\
\hline Partially & Not at all \\
\hline \multicolumn{2}{|c|}{$\begin{array}{l}\text { 2. Are technology assessment tools often used to check your knowledge of } \\
\text { English? }\end{array}$} \\
\hline Often & From time to time \\
\hline Seldom & Never \\
\hline \multicolumn{2}{|c|}{ 3. What technologies are mostly used by English teachers to control your skills? } \\
\hline Online tests & Emails \\
\hline Power Point Presentations & Educational portal \\
\hline \multicolumn{2}{|c|}{$\begin{array}{l}\text { 4. Are you satisfied with the results of an assessment by means of smart } \\
\text { technologies? }\end{array}$} \\
\hline Completely satisfied & Satisfied \\
\hline \multirow[t]{2}{*}{ Very satisfied } & Dissatisfied \\
\hline & Very dissatisfied \\
\hline \multicolumn{2}{|c|}{$\begin{array}{l}\text { 5. Do smart technologies used in the classroom to assess your skills motivate and } \\
\text { encourage you to reach better results? }\end{array}$} \\
\hline Yes & Partially \\
\hline \multicolumn{2}{|l|}{ No } \\
\hline $\begin{array}{l}\text { 6. What are the pros and } \\
\text { skills? }\end{array}$ & of using smart technologies to assess English \\
\hline
\end{tabular}

In response to the 1 st research question to determine the participants' attitude towards using technology as a tool of assessment in the classroom the students overwhelmingly answered positively $76 \%$ (yes), 14\% (partially) underlining the strong support to digital technology integration. Almost $10 \%$ of the students responded negatively due to digital illiteracy. Technical problems they faced during their work led to negative computer attitudes. Despite the fact that the trend is mostly positive the change won't happen overnight. Time and great efforts of the teachers are needed to make students less resistant to the process of digitalization.

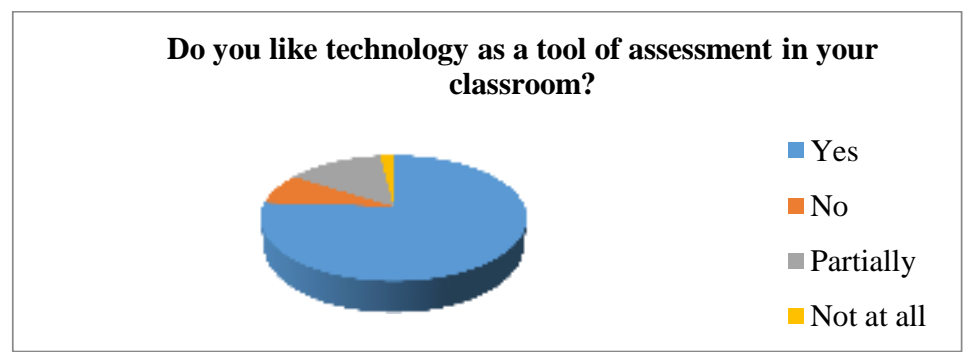

Figure 1: Students' answers to question 1

In order to find out the frequency of use of the technological devices available, an explicit question was asked: «Are technology assessment tools often used to check your knowledge of English»? Here, according to students' opinion technology as a tool of assessment is implemented in teaching practices from time to 
time $(54 \%)$ or quite seldom $(25 \%)$. These results prove the fact that teachers are not ready to integrate technology into their classrooms as they do not have the necessary know-how related to the different aspects blended learning, mobile learning, and so on. Here is the existing mismatch between teacher training and the needs of the real world - students' positive perception of technology integration into EFL teaching and assessment.

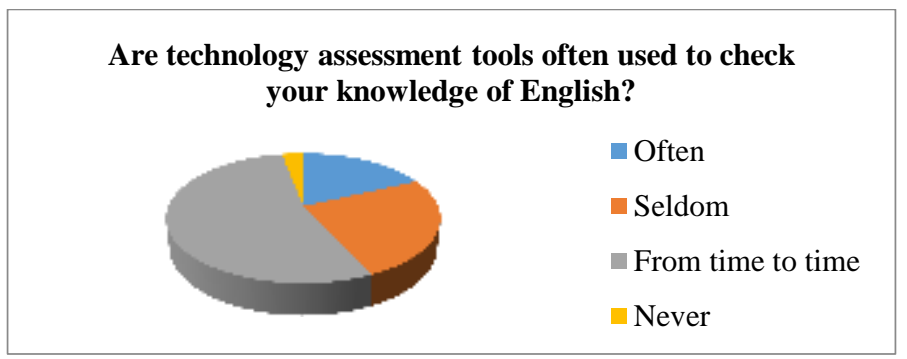

\section{Figure 2: Students' answers to question 2}

For a better understanding of the availability of the technological facilities, the respondents were asked about their opinions related to the tools used to estimate knowledge of the English language. Here, there was an inconsistency among the answers: the students considered that power point presentations (48\%) and online tests $(40 \%)$ were mostly used by English teachers. The least popular tool of assessment was educational portal (4\%). Data analysis reflects that teachers are mostly in favor of the technologies that are less time consuming.

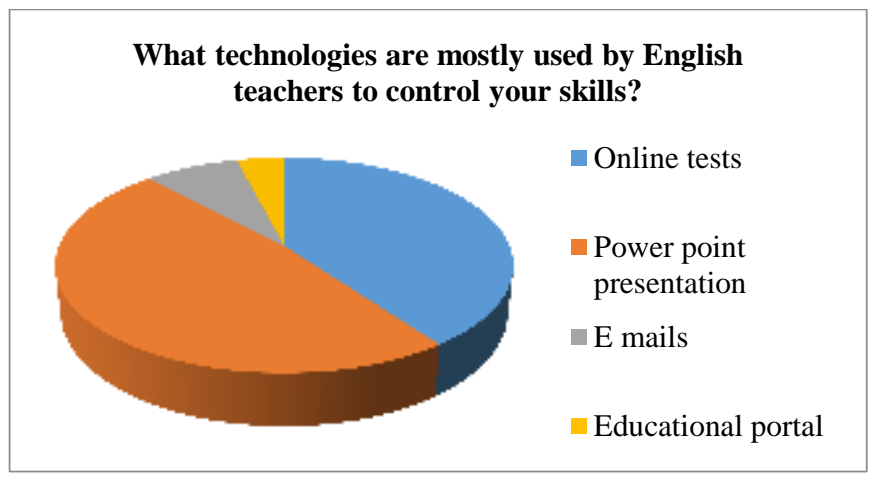

\section{Figure 3: Students' answers to question 3}

The $4^{\text {th }}$ and the $5^{\text {th }}$ questions explored the level of satisfaction and motivation by e-assessment. Responses to this question are presented in the graphs below. More than $50 \%$ of participated students were satisfied to some extent with the results of assessment. However the scientists should take keen interest in the negative concern of the respondents to motivate students to reach better results in EFL learning. $24 \%$ and $23 \%$ of students correspondingly felt dissatisfied and are not encouraged by implementation of smart technologies into EFL teaching. The percentage still remained relatively high.

XLinguae, Volume 11 Issue 1XL, January 2018, ISSN 1337-8384, eISSN 2453-711X 


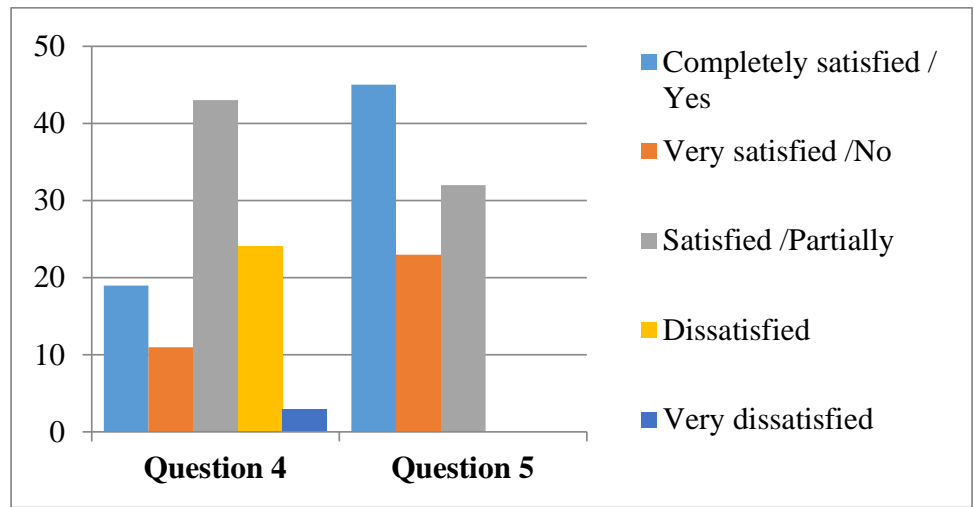

\section{Figure 4: Students' answers for questions4 and 5}

Finally, the 6th question offered the participants a freedom to name the advantages and disadvantages of using smart technologies to assess English skills. The positive aspects mentioned by the students were effective time management as assessments can be completed in less time and students are able to take the assessment during class, or at home, using their own device; objectivity and reliability; instant feedback. As for negative aspects, the respondents mentioned technical problems such as energy break and other things like that can lead to some delays; lack of detailed explanation for the wrong answers; academic dishonesty can take place. Undoubtedly, the benefits outweigh the drawbacks but choosing the correct technology or a range of technologies to reach some learning objectives results in the creation of a more engaged classroom and improved student learning. Based on the literature review and our findings we have integrated several technologies (online tests, powerpoint presentations, e-mails and educational portal) into the course of «Business communication». The main aim was development of intercultural communicative competence (ICC) including problem-solving skills and analytical, critical and creative thinking in students' work. Within the course the focus was made not just on the use of technology but the role of the teacher. The teacher was a facilitator and a consultant to the students, rather than a dictator and the center of the teaching process. On the bases of data collected by the analysis of scientific literature we figured out the following characteristics of smart technologies:

Table 2: Smart technologies' characteristics

\begin{tabular}{|c|c|c|}
\hline $\begin{array}{l}\text { Smart } \\
\text { technologies }\end{array}$ & Didactic characteristics & Didactic functions \\
\hline $\begin{array}{l}\text { PowerPoint } \\
\text { Presentation }\end{array}$ & $\begin{array}{ll}\text { - } & \text { Access to various sources of } \\
\text { - } & \text { Flucational information } \\
\text { - } & \text { Integrity } \\
\text { - } & \text { Openness } \\
\text { - } & \text { Advanced visualization } \\
\text { - } & \text { Operational control of } \\
\text { educational achievements } \\
\text { - Possibility of organizing } \\
\text { individual students' work to } \\
\text { develop their cognitive } \\
\text { independence and creativity } \\
\text { - Multifunctionality }\end{array}$ & $\begin{array}{l}\text { - Informatization of the } \\
\text { educational process } \\
\text { - Formation } \\
\text { information culture of } \\
\text { students } \\
\text { - Possibility of } \\
\text { organizing a discussion } \\
\text { - The ability to perform } \\
\text { group and individual } \\
\text { projects } \\
\text { - Organization } \\
\text { research work of } \\
\text { - Developing students }\end{array}$ \\
\hline
\end{tabular}




\begin{tabular}{|c|c|c|}
\hline & $\begin{array}{l}\text { - Interactivity } \\
\text { The ability to store and } \\
\text { transfer information of } \\
\text { various formats (text, } \\
\text { graphics, video, audio) }\end{array}$ & $\begin{array}{ll}\text { into independent } \\
\text { learners } \\
\text { - Development } \\
\text { cognitive activity of } \\
\text { students } \\
\text { - Development } \\
\text { professional skills } \\
\end{array}$ \\
\hline E-mail & $\begin{array}{l}\text { - Sending text and other } \\
\text { information (as attachments) to } \\
\text { one or several users } \\
\text { - Storing the received information } \\
\text { (text, graphic, audio, video- } \\
\text { limited sizes) on the hard disk } \\
\text { - Organizing telecommunication } \\
\text { projects for information exchange } \\
\text { between participants }\end{array}$ & $\begin{array}{l}\text { - Increasing control over } \\
\text { planning, composing, } \\
\text { editing, delivering } \\
\text { messages than in face- } \\
\text { to-face communication } \\
\text { - Giving opportunity to } \\
\text { look back at the } \\
\text { received and sent } \\
\text { messages } \\
\text { - Facilitating reflective } \\
\text { learning } \\
\text { - Providing students with } \\
\text { a real audience with } \\
\text { whom to communicate } \\
\text { and interact } \\
\text { - Improving writing } \\
\text { skills } \\
\text { - Encouraging } \\
\text { motivating students by } \\
\text { bringing the content } \\
\text { and the subject matter } \\
\text { to real life }\end{array}$ \\
\hline Online test & $\begin{array}{l}\text { - Interactivity } \\
\text { - The ability to record all stages of } \\
\text { control } \\
\text { - Objectivity of the results } \\
\text { - Operational control of } \\
\text { educational achievements } \\
\text { - Assessment of language } \\
\text { knowledge and ability in English }\end{array}$ & $\begin{array}{l}\text { - Improving the } \\
\text { effectiveness of } \\
\text { control by increasing } \\
\text { the frequency and } \\
\text { regularity of testing } \\
\text { - Implementation of } \\
\text { the same rules for all } \\
\text { students to conduct } \\
\text { pedagogical control } \\
\text { and adequate } \\
\text { interpretation of test } \\
\text { results } \\
\text { The compatibility of } \\
\text { the test technology } \\
\text { with other modern } \\
\text { educational } \\
\text { technologies }\end{array}$ \\
\hline $\begin{array}{l}\text { Educational } \\
\text { Portal }\end{array}$ & $\begin{array}{l}\text { - Publicity (it is available to all } \\
\text { project participants located at a } \\
\text { distance from each other) } \\
\text { - Modernization } \\
\text { - Multimedia (the ability to use }\end{array}$ & $\begin{array}{l}\text { - Development of socio- } \\
\text { cultural skills } \\
\text { - The ability to comment } \\
\text { on posted information, } \\
\text { express your views }\end{array}$ \\
\hline
\end{tabular}

XLinguae, Volume 11 Issue 1XL, January 2018, ISSN 1337-8384, eISSN 2453-711X 


\begin{tabular}{|l|l|lr|}
\hline & $\begin{array}{l}\text { materials in different formats: } \\
\text { text, photo, video, audio material } \\
\text { when creating content) }\end{array}$ & $\begin{array}{l}\text { Developing the skills of } \\
\text { independent learning } \\
\text { activities r } \\
\text { - Development r of } \\
\text { students, cognitive } \\
\text { activity }\end{array}$ \\
\hline
\end{tabular}

The integration of smart technologies into the course of «Business communication» revealed not just only the benefits but also some blocking factors which affected smart technology integration. Firstly, students' and teachers' digital illiteracy led to the result that $25 \%$ of students think that technology-mediated teaching/assessment seldom implemented in educational process. Secondly, technical problems caused demotivation in language acquisition. Thirdly, limited resources definitely resulted adversely in technology-enhanced activity.

\section{Conclusion}

Thus the study has highlighted the blocking factors of smart technology integration. It shows the importance and urgency of addressing and verbalizing these issues in class as a part of the foreign language curriculum.

Despite the problems, the effectiveness of the use of smart technology is possible in case teachers use them systematically; select appropriate teaching materials and prepare for classes. The task of the teacher is to organize and structure lessons in such a way that students will get the best cognitive outcome through using smart technologies so the lesson will activate cognitive activity of students and encourage students to identify their talents, abilities, and strengths, thereby increase self-confidence in the process of learning a foreign language.

Moreover, selecting relevant smart technologies contribute a great deal toward enhancing students' motivation and interest to EFL learning/assessment. The effectiveness of smart technology integration depends in many respects on finding an optimal balance between students' needs and teachers' professional competence (Klimova et al., 2017: 394). Our investigations into this area are still ongoing. This research has thrown up many questions in need of further examination of smart technology integration into EFL teaching at the non-linguistic higher school.

\section{Acknowledgments}

The work is performed according to the Program of Development of Federal StateFunded Educational Institution of Higher Education "Financial University under the Government of the Russian Federation" for 2020.

\section{Bibliographic references}

ANDRADE, M. 2014. Role of Technology in Supporting English Language Learners in Today's Classrooms. Copyright by Maria Andrade. P.58. Available online: https://tspace.library.utoronto.ca/bitstream/1807/66995/1/Andrade_MariadeLourdes_2 01406_MT_MTRP.pdf

ARK, T. V. 2016. Supporting English Language Learners with Next-Gen Tools. Available online: http://www.gettingsmart.com/2016/05/supporting-english-languagelearners-with-next-gen-tools/

BEAUVOIS, M. 1998. Conversations in slow motion: Computer-mediated communication in the Foreign Language Classroom. In: The Canadian Modern Language Review, vol. 54, n.2, pp. 198-217. Available online: http://utpjournals.press/doi/10.3138/cmlr.54.2.198

CHAPELLE, C. - DOUGLAS, D. 2006. Assessing Language through Computer Technology. ISBN 9780521549493. 
DUROCHER, K. 2016. The Importance of Balancing Classroom Technology Use. Available online: http://www.gettingsmart.com/2016/12/technology-productively-inthe-classroom/

DUDENEY, G. - HOCKLY, N. 2007. How to teach English with Technology (with CD-Rom) Pearson - Longman. P.192. ISBN 978-1-4058-5308-8.

JOHANNESEN, T. - EIDE, E.M. 2000. The role of the teacher in the age of technology: Will the role change with use of Information- and communication technology in education? Available online: http://www.eurodl.org/materials/contrib/2000/eide3/eide3.html

KHUZIAKHMETOV, A.N. - GABDRAKHMANOVA, R.G. 2016. Creativity in joint activity of teacher and student in the learning process. In: IEJME - Mathematics Education, vol. 11, n. 4, pp. 735-745. ISSN 2468-4945

KHUZIAKHMETOV, A.N. - NASIBULLOV, R.R. 2016. Dialectics of correlation of the school student personality socialization and individualization in pedagogical theory and practice. In: IEJME - Mathematics Education, vol. 11, n. 4, pp. 475-487. ISSN 2468-4945

KHROMOV, S.S. - ROMANOVA, S.A. 2013. Smart technologies in teaching foreign languages and the Russian language as a foreign one: new quality, and paradigm of education In: New technologies in the educational space of national and international language.n. 1. pp. 113-119.

KONG, Y. - KAYUMOVA, L.R. - ZAKIROVA, V.G. 2017. Simulation Technologies in Preparing Teachers to Deal with Risks. In: EURASIA Journal of Mathematics, Science and Technology Education, vol. 13, n. 8, pp. 4753-4763. . ISSN: $13058215,13058223$.

LI, N. - PYRKOVA, K.V. - RYABOVA, T.V. 2017. Teaching Communication Skills and Decision-Making to University Students. In: EURASIA Journal of Mathematics, Science and Technology Education, vol. 13, n. 8, pp. 4715-4723. ISSN $13058215,13058223$.

LITON, H. A. 2015. Examining Students' Perception \& Efficacy of Using Technology in Teaching English. In: International Journal of Education and Information Technology. vol. 1, n. 1, pp. 11-19. ISSN 2381-7410.

MASALIMOVA, A.R. - LEVINA, E.Y. - PLATONOVA, R.I. - YAKUBENKO, K.Yu. - MAMITOVA, N.V. - ARZUMANOVA, L.L. - GREBENNIKOV, V.V. MARCHUK, N.N. 2017. Cognitive Simulation as Integrated Innovative Technology in Teaching of Social and Humanitarian Disciplines. In: EURASIA Journal of Mathematics, Science and Technology Education, vol. 13, n. 8, pp. 4915-4928. ISSN $13058215,13058223$.

MERÇ, A. 2015. Using Technology in the Classroom: A Study with Turkish PreService EFL Teachers. In: TOJET: The Turkish Online Journal of Educational Technology, vol.14, n. 2, pp. 229-240. ISSN 2146-7242.

ORDEN, V.S. 2010. Integrating Digital Technologies in the German Language Classroom: A Critical Study of the Technology Integration Experiences of Three Secondary German Teachers. All Graduate Theses and Dissertations. p. 796. Available online: https://digitalcommons.usu.edu/etd/796.

OXFORD DICTIONARIES Available online:

https://en.oxforddictionaries.com/definition/smart

OGURTSOVA, O. 2015. Teaching business English in the new digital age. In: Pedagogical Process: theory and practice, vol.46-47, n.1-2, pp. 83-88. ISSN 2078 1687.

SANDOLO, L. 2010. How can the use of Technology enhance writing in the classroom? Education Masters. Paper Available online: 19. 
https://fisherpub.sjfc.edu/cgi/viewcontent.cgi?article=1195\&context=education_ETD _masters

SHYAMLEE, S. D. - PHIL, M. Use of Technology in English Language Teaching and Learning: An Analysis. 2012. International Conference on Language, Medias and Culture IPEDR., vol.33 IACSIT Press, Singapore. Available online: http://www.ipedr.com/vol33/030-ICLMC2012-L10042.pdf

THE FUTURE OF HIGHER EDUCATION: HOW TECHNOLOGY WILL SHAPE LEARNING. THE ECONOMIST INTELLIGENCE UNIT 2008. Available online: https://www.nmc.org/pdf/Future-of-Higher-Ed-(NMC).pdf THE FUTURE OF HIGHER EDUCATION: HOW TECHNOLOGY WILL SHAPE LEARNING. The Economist Intelligence Unit 2008. Available online: http://graphics.eiu.com/upload/the\%20future\%20of\%20universities.pdf

VASBIEVA, D. G. - KLIMOVA, I. I. 2015. Transformational potential of blended learning to personalize foreign language teaching in a non-linguistic higher school. XLinguae, vol. 8, n. 1, pp. 2-10.

Words: 4095

Characters: 29292 (16,27 standard pages)

Assoc. Prof. Olga A. Kalugina

Department of Foreign Languages

Financial University under the Government of the Russian Federation

Leningradsky prospect 49

125993 Moscow

Russia

kaluginaruc@mail.ru

Assoc. Prof., Natalya A. Tarasevich, Ph.D.

Brest State University named after A.S. Pushkin

21 Boulevard Kasmanautau

224016 Brest

Belarus

tarasevich56@gmail.com 